\title{
Does Divestment Risk Evolution of MNE Subsidiaries Display an Inverse U-Shaped Form?
}

\author{
Antonios Georgopoulos* \\ University of Patras, Rio Patras, Greece \\ Vasilios Sogiakas \\ The American College of Greece, Athens, Greece
}

\begin{abstract}
The current study investigates the evolutionary path of divestment risk of MNE subsidiaries in a regionally integrated area. Although descriptive statistics tend to indicate an inverse U-shaped path of divestment risk for the whole post-war era (1960 2015), including the protectionism period (1960 1980), the Kaplan-Meier survivor curve is monotonically decreasing across the three successive stages of EU integration (1981 2015). Moreover, the econometric findings exhibit that divestment risk stabilization at the deep integration stage is due to investment in product differentiation and human capital and not to factor differentials such as tariffs and wage costs. To our best knowledge, this is the first study that explores the evolution of foreign divestment risk in a gradually increasing integrated environment.
\end{abstract}

JEL Classifications: F15, F23

Keywords: MNE subsidiary, Economic integration, Greece

\footnotetext{
* Corresponding Author: Antonios Georgopoulos; Professor, Department of Business Administration, University of Patras, University Campus, 26504 Rio Patras, Greece, Tel: +302610996139, email: georgop@upatras.gr

Co-Author: Vasilios Sogiakas; Lecturer, The American College of Greece, Tel: +306983601100, email: vasilios.sogiakas@glasgow.ac.uk 


\section{Introduction}

This paper is based on a controversial debate that took place during the 1980s and early 1990s on the de-industrialization impact of European integration on Mediterranean economies such as Greece, Spain, and Portugal (Murolo 1982, Bliss and Braga de Macedo 1990, Krugman and Venables 1990, Oughton 1993), especially as ex-post empirical analyses revealed considerable de-industrialization effects on these countries (United Nations Conference on Trade and Development, UNCTAD:www.unctad.org/wir). Such effects substantially increased foreign divestment risk because the production decisions of foreign MNEs are sensitive to institutional change (Bliss and Braga de Macedo 1990, Krugman and Venables 1990, Amin and Malmberg 1992, Young et al. 1994, Benito et al. 2003). The divestment of foreign investment risk caused the closure of important local manufacturing subsidiaries. Although there is voluminous literature on foreign divestment, we know less about the divestment consequences of regional integration (Richbell and Watts 2000, Benito et al. 2003, Belderbos 2003). Moreover, we are much less aware of the evolutionary path of foreign divestment risk while an economy is passing through one stage of economic integration into the next. Given that the evolutionary form of foreign divestment risk in Southern Europe also remains totally unexplored (as it unfortunately was overtaken by fiscal and monetary integration-driven issues), this paper seeks to shed new light on the earlier debate and addresses MNE subsidiary divestment risk at every important individual integration stage.

This article is specially motivated by Krugman and Venables (1990) who in the early 1990s observed the choice of the EU's industrial location between its geographic core (i.e., Central and Northern European countries) and its periphery (i.e., Southern European countries) as a dynamic response of producers to lowering the barriers to trade and a variation of wage levels (also Bliss and Braga de Macedo 1990). In particular, they initially observed good industrial prospects for Southern European economies in protectionism and painful deindustrialization effects because of reduced tariffs in an increasingly integrated environment. Finally, in a low-cost situation at deep integration, they expected that factor price differentials might pull production to low-cost Southern Europe, thereby strengthening their industrial chances again. Thus, they proposed that the industrial evolution of Southern economies might reveal a U-shaped relationship. According to the spirit of the two authors, we test whether foreign divestment risk path reversely takes an inverse U-shaped form by defining such a risk as the discontinuation of manufacturing operations of a business.

In light of the paucity of prior literature (Benito 1997, Richbell and Watts 2000, Belderbos 2003, Benito et al. 2003), we explicitly examine foreign divestment risk across sequential integration stages of the Greek economy, which faced a wide de-industrialization after its entry into the EU in 1981 (Murolo 1982, Bliss and Braga de Macedo 1990). Greece provides a highly researched site for this study because its emerging economy has undergone different stages of regional integration and with different degrees of influence in its industrial production. Our unique database guarantees an exact analysis of the historical evolution of MNE subsidiaries located in the host economy. Thus, we are able to respond to how and why 
their divestment risk changed in moving from one integration stage to another, i.e., from the shallow integration scheme of the single market (1981 1991) to the deeper integration form of the Maastricht agreement (1992 2001), and finally to the more integrated environment of the Eurozone (2002 2015). Divestment risk evaluation follows at each integration stage of the economy. From this point of view, we expect that divestment risk varies according to the evolution of specific contradictory factors (about these factors, Benito 2005). More specifically, we consider that location-bound assets, such as product differentiation and human capital that are unique and country-specific, might provide protection against import competition so reducing divestment risk (Meyer et al. 2011). By contrast, the abolition of tariffs might result in rising import competition (Manolopoulos et al. 2007, Pearce and Papanastasiou 1997) and the increase in wage rates might make production units and industries non-competitive at an international level (Narula and Dunning 2000), producing adverse divestment effects.

Our paper contributes to the rare integration literature on MNE subsidiary divestment and compares for the first time variables with contradictory divestment outcomes at each integration stage of the economy. The descriptive statistics support an inverse U-shaped divestment path in the Greek environment during the total post-war era, which is very similar to those of the other Mediterranean countries. Thus, they are in line with the main proposition of Krugman and Venables (1990) with regard to a U-shaped evolutionary form of manufacturing production in Southern Europe during integration. Focusing on the integration period, we find that the Kaplan-Meier survivor curve is monotonically decreasing across the three successive stages of EU integration (1981 2015). Additionally, the findings suggest that divestment risk stabilization at deeper integration stages is not a product of factor differentials (as predicted by the above authors), but an outcome of investment in locationbound assets such as product differentiation and human capital.

\section{The Approach of Krugman and Venables to Divestment Risk Evolution}

The main characteristics of the relevant debate during the 1980s and 1990s (Murolo, 1982, Bliss and Braga de Macedo 1990, Krugman and Venables 1990, Oughton 1993) referred to the ambiguous impact of the EU entry of the Southern European countries on their manufacturing production. Within this debate, particular emphasis was given to the structural adjustment and the possible relocation scenarios of manufacturing activity between the European core and its periphery. It should be mentioned that Krugman and Venables (1990) were among the pioneers who explored different (de-) industrialization scenarios, providing an explanation of the impact of trade cost reduction and wage level differentiation on the (re-) location and competitiveness of local industries in the single market. The authors considered the choice of industrial location within the EU area as a U-shaped response of local manufacturing production to a fluctuation of trade and labor costs. In this way, they indicated indirectly an inverse U-shaped form of divestment risk. More precisely, in the 
case of high trade costs (protectionism) Krugman and Venables (1990) claimed that each member country possesses a share of manufacturing that equals its endowments. In this case, individual protected markets have to be served through domestic firms or foreign production subsidiaries that replace imports. At this stage, divestment risk is low since high trade barriers may contribute to dispersed MNE production (Krugman and Venables 1996, Fujita and Krugman 2004). When trade costs decrease, economies of scale start to dominate and production tends to be concentrated in the central European region with its large market (Krugman and Venables 1990). Thus, the lowering of trade barriers is closely connected with an increase of foreign divestment risk. As integration further deepens and tariffs are totally abolished, divestment risk substantially rises. A drastic lowering of trade barriers motivates MNEs to concentrate their production units in a small number of industrial districts in the European core (Krugman and Venables 1996, Pearce and Papanastassiou 1997, Benito et al. 2003, Fujita and Krugman 2004) even if this tendency goes against the relative factor endowments of the European South (Krugman and Venables 1990). Their analysis responded to the question of why firms agglomerate in certain places as integration deepens (Fujita and Krugman 2004) and implies that in the dynamic world of imperfect competition and economies of scale (Krugman 1980, Benito 1997), divestment risk considerably increases in Southern economies (Pearce and Papanastassiou 1997). This trend was confirmed empirically in the case of Greece, where foreign MNEs closed a large number of their small manufacturing sites during its European integration (Manolopoulos et al. 2007).

For a very low trade costs scenario (deep integration), Krugman and Venables (1990) argued that the location of manufacturing production is primarily driven by factor market competition, which acts as a dispersion force. Therefore, they claimed that firms relocate to take advantage of factor price differentials between member countries and pull production to the low-cost periphery. At this stage, they expected that Southern European countries would be able to offer a compensating wage differential to offset the disadvantage caused by their peripheral location (other things being equal).

Instead of favorable factor price differentials, we propose that location-bound assets might contribute to divestment risk stabilization at lower levels (Meyer et al. 2011) in Southern European countries as they can create local responsiveness (Benito 2005, Ghemawat 2007, Perez-Batres and Eden 2008, Meyer et al. 2011) that arises from the need for the "adaptation of products and their marketing to suit local demand patterns, cultivating connections to local authorities, or the use of localized resources" (Benito 2005: 204). We further argue that local responsiveness that might reduce subsidiary divestment risk, particularly becausean emerging market with weak institutional strength (Luo 2003, Delios et al. 2008) can arise from massive investment in product differentiation and human capital.

\section{Divestment Risk Evolution in the Greek Economy}

The starting point of the analysis in Greece is at the end of the era of protectionism (1960 1980). During that era, foreign MNEs established new units in the emerging Greek 
economy either to overcome protectionist barriers or to supply labor-intensive products. Thus, the number of new foreign establishments grew rapidly and reached 214 in 1980 (Figure 1). The combination of EU integration with diverse levels of trade barriers (Krugman and Venables 1990) produced deep and shallow integration schemes as suggested by Benito et al. (2003). Given that national development and integration paths are unique and following Benito et al. (2003), we divide the EU integration of Greece into three successive time periods and characterized by the single market (1981 1991), the Maastricht agreement (1992 2001), and the Eurozone (2002 2015), respectively. In our analysis, the integration process began in 1981 with 214 MNE subsidiaries and ended in 2015 with 106 survivors and 108 divested units (Figure 1). We found that foreign divestment risk varied across time, which provided an important research framework for our investigation. In particular, we concluded that from the 108 units that divested in the total integration period, 16 divested in the first stage, 83 shut down in the second stage, and 9 units closed in the third integration stage (Figure 1).

Integration Stage I. The single market (1981 1991): The beginning of this stage was marked by the entry of Greece to the EEC (later the EU). During that stage, Greece's regional incorporation took place gradually in an environment of moderate tariff adjustment. Similarly, the observed reduction in labor cost differentials was not significant enough to bridge the corresponding wage gap between Greece and Central and Northern Europe. Overall, 16 foreign units divested at that time (Figure 1) due to the failure of product differentiation and human capital to reach high levels (Figure 2).

Integration Stage II. The Maastricht agreement (1992 2001): Trade and financial liberalization proceeded and several common economic policies were established for the achievement of the Maastricht agreement targets. As a result, protection was totally abolished and economic growth along with an aggressive wage policy led to the steep rise of labor cost. In the new economic regime, the Greek economy experienced immense structural adjustment, which caused an enormous increase in divestment risk. At that time, over 80 foreign units divested (Figure 1) as the development of location-bound factors, such as differentiated products and local human capital(despite their clear upward trend, Figure 2), could not outweigh the adverse integration effects.

Integration Stage III. The Euro era (2002 2015): After the introduction of the common currency, a new financial and economic-political environment emerged that provided the biggest integration stimulus between the Greek and the regional economies. Unsurprisingly, the process of wide industrial restructuring of the first two integration stages was almost complete and many protected MNE subsidiaries had already closed, thus rationalization and efficiency across markets dominated. The surviving units invested intensively in location-bound assets, whereas the adverse impact of wages on divestment risk reduced considerably (Figure 2) due their reducing importance in total operation costs of subsidiaries. Consequently, only nine units closed down and divestment risk stabilized at a relatively low level (Figure 1).

Figure 3 depicts the specific chronological evolution of the number of sample subsidiaries in operation during the entire post-war era (1960 2015), including protectionism 
(1960 1980). At the end of the period of protectionism, 214 subsidiaries, which had gradually increased in number over the period, were in operation. With the start of the integration process (although the number of survived units continued to remain high, 198), the situation began to slowly revert. By the end of Stage II, the number of the survived units declined sharply (115) and then stabilized at a somewhat lower level (106) at the end of Stage III, reflecting an inverse U-shaped divestment risk path over the whole post-war period.

Figure 4 exclusively concerns the integration period (1981 2015) and displays the Kaplan-Meier survivor curve, representing the non-parametric statistic used to estimate the survival function from lifetime data. The figure also shows that the survivor curve is monotonically decreasing during the integration process.

\section{Figure 1. The sample of MNE subsidiaries}

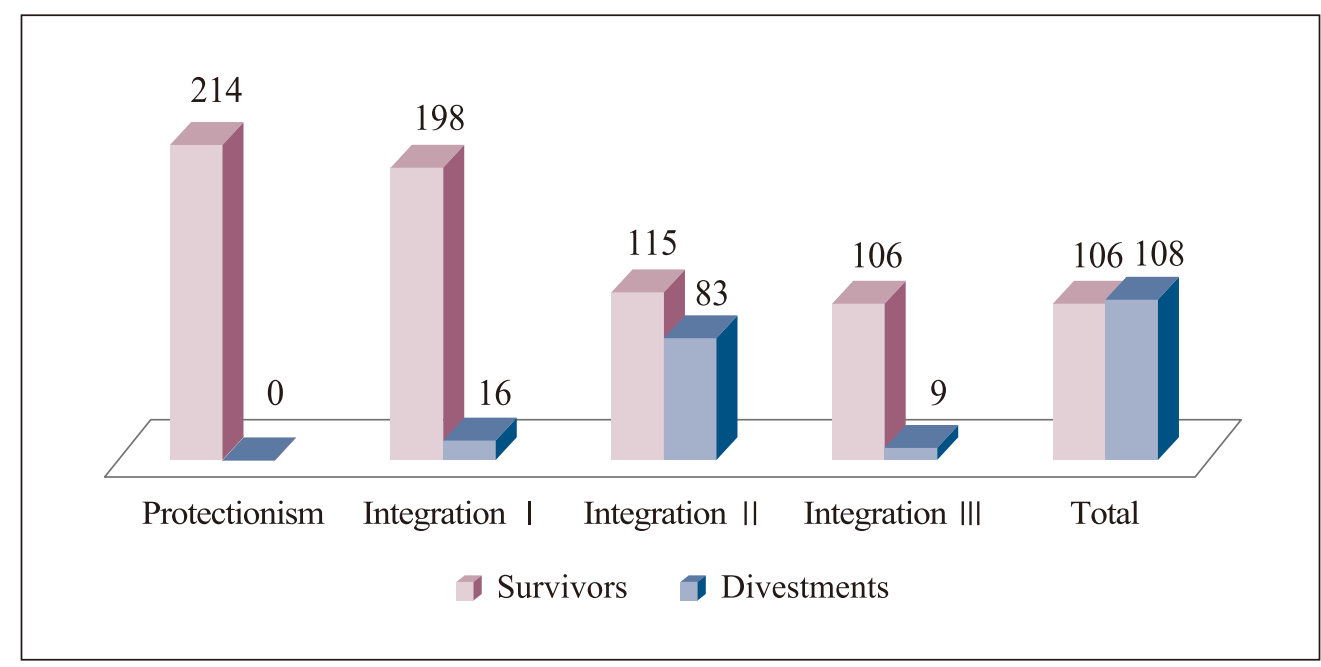

(Source) Processing of data of foreign Chambers of Industry and Commerce

Figure 2. Mean value of explanatory variables

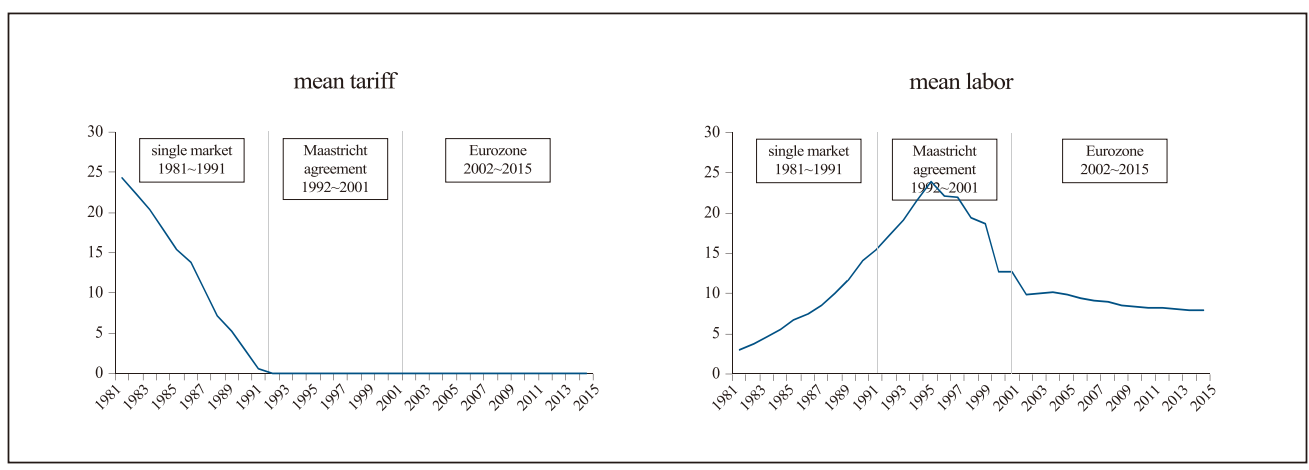




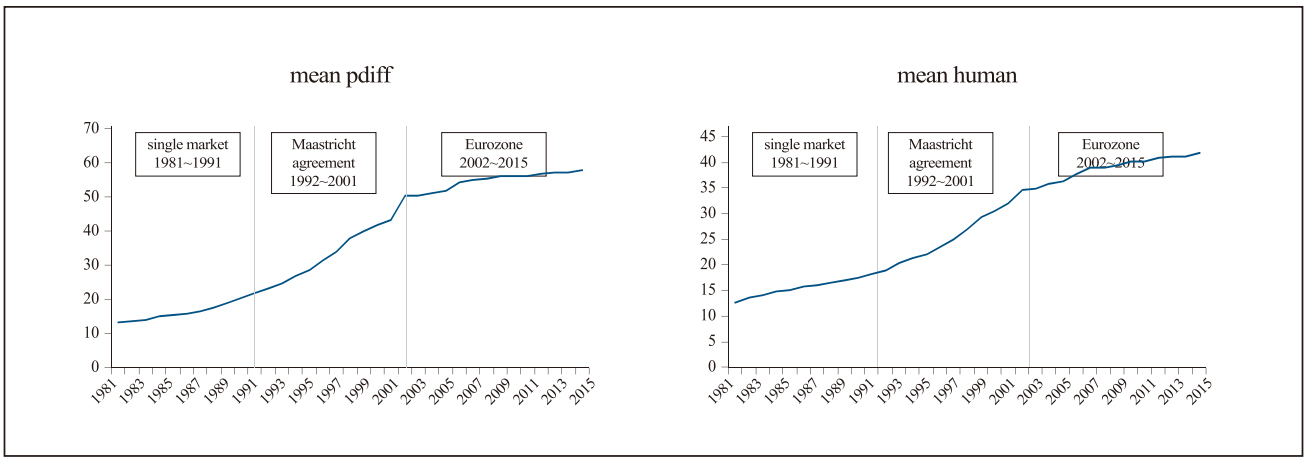

Figure 3. MNE subsidiary evolution

(subsidiary numbers per year)

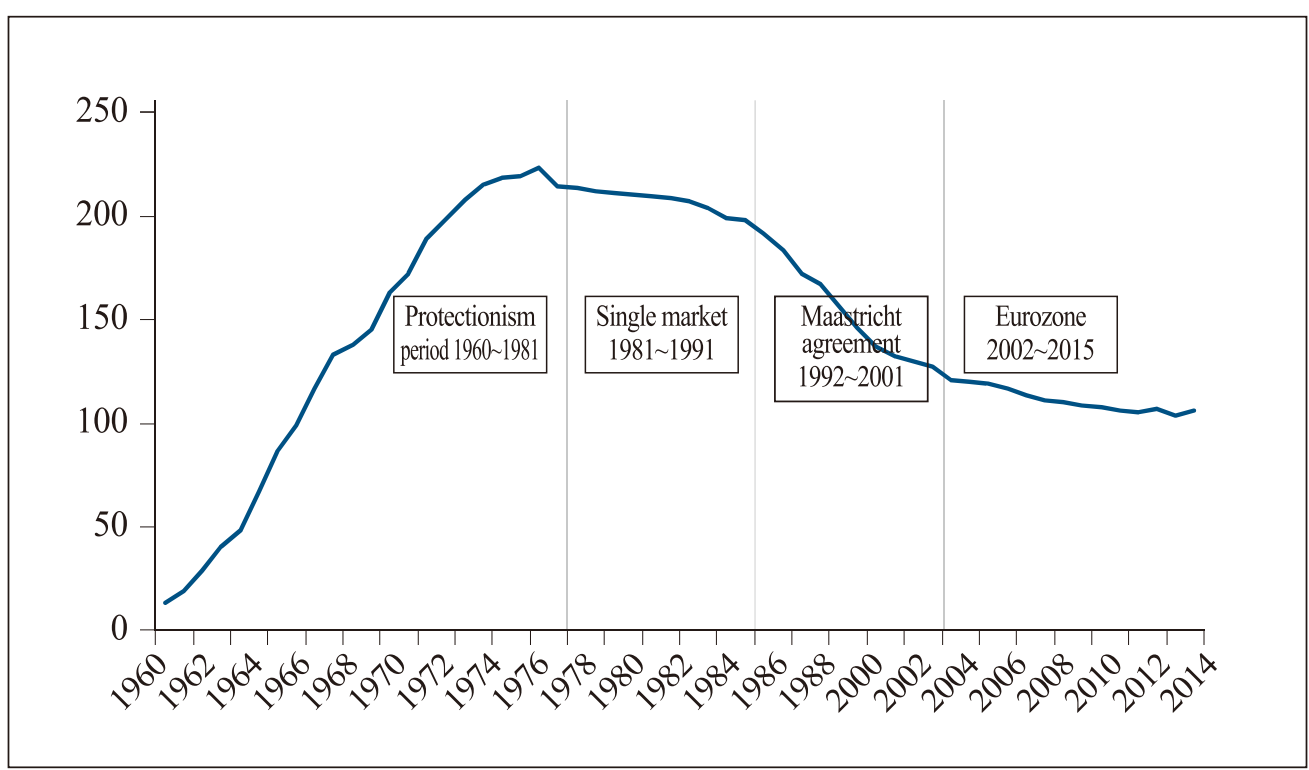

(Source) Processing of data of foreign Chambers of Industry and Commerce 
Figure 4. Kaplan - Meier survival analysis

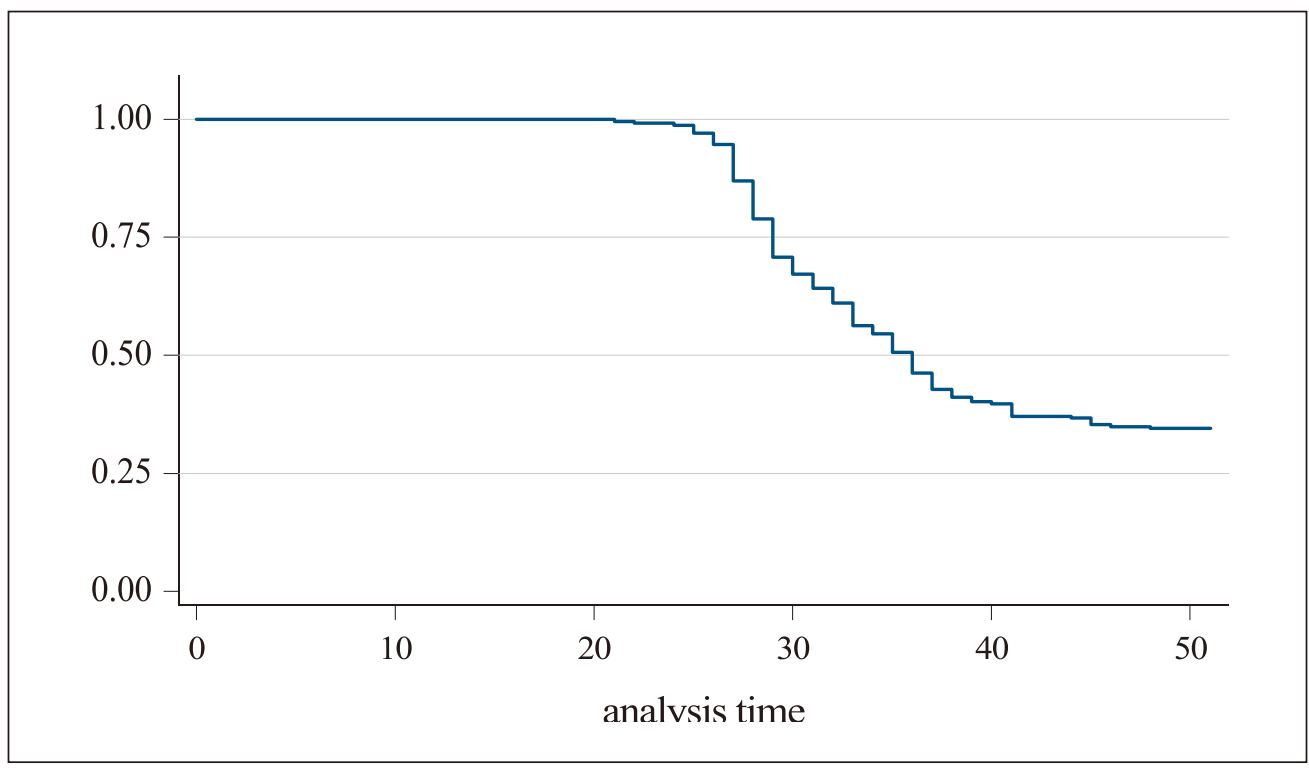

(Source) Processing of data of foreign Chambers of Industry and Commerce

\section{Research Methods}

\section{A. Sample and data set}

Foreign manufacturing subsidiaries located in Greece are identified from official records provided by foreign Chambers of Industry and Commerce situated in each country. The specific records contain all foreign manufacturing local units with full data including address, location, year of establishment, management, product groups, and industrial sector. Annual reports for these subsidiaries are offered from the comprehensive database of ICAP Hellas, which includes systematic financial and non-financial information (e.g., sales, export, labor force, performance) on all manufacturing companies operating in Greece since 1981 (the year of entry of Greece to the EU).

From this sampling frame, we explicitly focus on 214 units that were established during protectionism (1960 1980, see Table 1) through Greenfield investments, which constituted the vast majority of the total MNE subsidiary population ( $>75 \%)$ that operated in Greece during the total post-war era and created the same starting institutional and environmental context of operation as reflected in high protection rates and low domestic wages. Each investment belonged to a different foreign MNE group and evolved over 35 years (1981 2015) to reveal an interesting evolutionary path that is either survived or divested at some point during the period under investigation. 
We excluded nine units from the analysis, e.g., minority joint-ventures (foreign participation $<30 \%$ ), bankruptcies characterized by low foreign influence on governance, and short-term financial distress. We also did not consider foreign acquisitions that gained subsequent importance during EU integration (also Blevins et al. 2016). These units exhibited high performance (Georgopoulos and Preusse 2009) and, inevitably, very low divestment risk as only 5 out of $60(8 \%)$ shut down during the whole integration period under consideration. In this way, we guaranteed that divestment risk was primarily caused by long-term institutional and environmental change.

Our database is unique as it comprises the historical evolution of sample subsidiaries from year to year. Additional information on their microeconomic variables comes from our archive, which is based on previous extensive primary surveys on multinational companies in Greece. This provides our study originality.

\section{B. Variables}

The distinction between divested and non-divested subsidiaries is captured by a dependent dummy variable that takes a value of one in the case of divestment and zero otherwise. In the whole article, we define as a divestment the discontinuation of manufacturing operations of a business. Thus, even if the business continues to operate in the local market in another form (e.g., as an import company), we consider it as a divested unit. We select four explanatory variables (Table 1), tariffs, labor cost, product differentiation, and human capital, based on the theoretical overview of Benito (2005) as well as Krugman and Venables (1990) who showed clearly the role of tariffs and labor costs in the prospects of integration of the Southern European economies in the EU. At the core of the analysis we place two crucial location-bound factors: product differentiation and human capital. Product differentiation (in terms of producing different varieties of a final good) may be an important factor to prevent divestment due to its uniqueness and immunity to import competition (Pennings and Sleuwaegen 2000, Delios and Beamish 2001, Anand and Delios 2002). Product differentiation is strongly linked with advertising intensity, which has been used to measure brand equity (Anand and Delios 2002, Pennings and Sleuwaegen 2000). It is also linked with international trade and FDI (Caves 1971), and new economic geography (Krugman 1990). In turn, the presence of qualified localized assets, such as human capital, reflects human resource management practices that may be most strongly influenced by local isomorphism (Rozenzweig and Nohria 1994). The availability of a copious supply of scientific personnel in the host country permits the pursuit of the necessary demand-side aims and the implementation of up-to-date management techniques in diverse fields of subsidiary activity (Manolopoulos et al. 2007), which might hamper divestment risk.

Given that subsidiary divestment risk may depend on several other factors, we control for subsidiary- (expo, size, and t_event), industry- (tech and open), and macro-specific characteristics such as GDP (Table 1). 
Table 1. Definition of the explanatory variables

\begin{tabular}{|c|c|c|c|}
\hline $\begin{array}{l}\text { Vari- } \\
\text { able }\end{array}$ & Rationale & Definition & Literature \\
\hline tariff & $\begin{array}{l}\text { The variable is used in order } \\
\text { to capture the impact of trade } \\
\text { barriers such as tariffs on } \\
\text { divestment risk. We expect } \\
\text { that high tariffs might reduce } \\
\text { divestment risk and reversely } \\
\text { (negative sign). }\end{array}$ & $\begin{array}{l}\text { Tariff expresses the average } \\
\text { nominal protection rate of the } \\
\text { main products of subsidiary } \\
\text { weighted by the percentile } \\
\text { share }(\%) \text { of local sales to total } \\
\text { subsidiary sales, as a purely } \\
\text { export subsidiary has no benefits } \\
\text { from tariff protection, that } \\
\text { is Tariff = average nominal } \\
\text { protection rate * local sales/ total } \\
\text { turnover }\end{array}$ & Culem 1988 \\
\hline labor & $\begin{array}{l}\text { The variable is used in order to } \\
\text { capture the impact of wages on } \\
\text { divestment risk. We expect that } \\
\text { low labor cost might decrease } \\
\text { divestment risk and reversely } \\
\text { (positive sign). }\end{array}$ & $\begin{array}{l}\text { labor is defined as the labor } \\
\text { cost unit over time, weighted } \\
\text { by the percentage share (\%) of } \\
\text { labor costs in total operating } \\
\text { subsidiary costs, since labor- } \\
\text { seeking subsidiaries intensify } \\
\text { the relative use of the specific } \\
\text { production factor, that is labor = } \\
\text { labor cost unit } * \text { labor cost/ total } \\
\text { operating cost. }\end{array}$ & $\begin{array}{c}\text { Culem 1988, } \\
\text { Mold } 2003\end{array}$ \\
\hline pdiff & $\begin{array}{l}\text { The variable is utilized to } \\
\text { demonstrate the impact of } \\
\text { advertising intensity on } \\
\text { divestment risk. We expect } \\
\text { that intensification of product } \\
\text { differentiation will reduce } \\
\text { divestment risk and reversely } \\
\text { (negative sign). }\end{array}$ & $\begin{array}{l}\text { pdiff is captured by the share (\%) } \\
\text { of advertising costs in subsidiary } \\
\text { turnover, reflecting a consistent } \\
\text { advertising policy, that is } \\
\text { pdiff = advertising cost/ turnover } \\
* 100 \% \text {. }\end{array}$ & $\begin{array}{l}\text { Caves 1971; } \\
\text { Krugman, } \\
\text { 1980, Delios } \\
\text { and Beamish } \\
\text { 2001, } \\
\text { Anand and } \\
\text { Delios 2002, } \\
\text { Pennings and } \\
\text { Sleuwaegen } \\
2000\end{array}$ \\
\hline human & $\begin{array}{l}\text { The variable human captures } \\
\text { the impact of human capital } \\
\text { intensity on divestment risk. We } \\
\text { expect that an increase in human } \\
\text { capital intensity will decrease } \\
\text { divestment risk and reversely } \\
\text { (negative sign). }\end{array}$ & $\begin{array}{l}\text { human is measured by the } \\
\text { share (\%) of degree holders } \\
\text { of university and technical } \\
\text { education (post-secondary } \\
\text { education) in the total labor } \\
\text { force of subsidiary, testing if } \\
\text { skill intensity influences its } \\
\text { divestment risk, that is human }= \\
\text { degree holders of post-secondary } \\
\text { education/ total labor force * } \\
100 \% \text {. }\end{array}$ & $\begin{array}{l}\text { Bernard and } \\
\text { Jensen } 2007\end{array}$ \\
\hline
\end{tabular}


(continued)

\begin{tabular}{|c|c|c|c|}
\hline $\begin{array}{l}\text { Vari- } \\
\text { able }\end{array}$ & Rationale & Definition & Literature \\
\hline$G D P$ & $\begin{array}{l}\text { The macroeconomic variable } \\
G D P \text { is used in order to check the } \\
\text { effect of economic environment } \\
\text { on divestment risk evolution, } \\
\text { especially under adverse } \\
\text { macroeconomic circumstances. } \\
\text { We expect an ambiguous } \\
\text { divestment risk impact, for } \\
\text { instance, in recession years GDP } \\
\text { might increase divestment risk } \\
\text { and vice versa. }\end{array}$ & $\begin{array}{l}G D P(\text { Gross Domestic Product) } \\
\text { is a macroeconomic variable } \\
\text { computed as annual real GDP } \\
\text { growth rates }(\%) .\end{array}$ & $\begin{array}{l}\text { Narual and } \\
\text { Dunning } \\
2000\end{array}$ \\
\hline expo & $\begin{array}{l}\text { The variable indicates the } \\
\text { impact of export status on } \\
\text { subsidiary divestment. A } \\
\text { surviving subsidiary with a } \\
\text { low export orientation may } \\
\text { exhibit exploitation of factors of } \\
\text { responsiveness to a high degree. } \\
\text { In turn, export-oriented units can } \\
\text { be more efficient than others. } \\
\text { Therefore, the expected sign is } \\
\text { ambiguous. }\end{array}$ & $\begin{array}{l}\text { Expo is a firm-specific variable } \\
\text { and captures the share }(\%) \text { of } \\
\text { export sales in total subsidiary } \\
\text { turnover, that is } \\
\text { Expo }=\text { export / total turnover } \\
* 100 \%\end{array}$ & $\begin{array}{l}\text { Bernard and } \\
\text { Jensen } 2007 \text {, } \\
\text { Colantone } \\
\text { and } \\
\text { leuwaegen } \\
2010\end{array}$ \\
\hline size & $\begin{array}{l}\text { The variable tests the impact of } \\
\text { economies of scale on divestment } \\
\text { risk. From this point of view, } \\
\text { a large business size might } \\
\text { guarantee survival, although } \\
\text { SMEs are more flexible and } \\
\text { more adaptable to environmental } \\
\text { change. Therefore, the expected } \\
\text { sign is ambiguous. }\end{array}$ & $\begin{array}{l}\text { Size is a firm-specific variable and } \\
\text { expresses the current subsidiary } \\
\text { size based on its labor force (ln). }\end{array}$ & $\begin{array}{l}\text { Benito } 1997, \\
\text { Bernard and } \\
\text { Jensen } 2007\end{array}$ \\
\hline t_event & $\begin{array}{l}\text { The variable examines whether } \\
\text { the length of tenure (learning } \\
\text { curve) may decrease the odds } \\
\text { of divestment. We expect that } \\
\text { mature units might present a } \\
\text { relatively low divestment risk } \\
\text { due to experience advantages and } \\
\text { reversely (negative sign). }\end{array}$ & $\begin{array}{l}\text { t_event is a firm-specific variable, } \\
\text { defined as the time period } \\
\text { between the time of establishment } \\
\text { and the time of divestment or } \\
\text { the final year of observation for } \\
\text { non-divested units (i.e. 2015), } \\
\text { that is } t \text { event for divested units } \\
=\text { time of divestment - time } \\
\text { of establishment or } t \text { event } \\
\text { for non-divested units }=\text { time } \\
\text { of observation - time of } \\
\text { establishment }\end{array}$ & $\begin{array}{c}\text { Benito 1997, } \\
\text { Mudambi } \\
\text { and Zahra } \\
2007\end{array}$ \\
\hline
\end{tabular}


(continued)

\begin{tabular}{|c|c|c|c|}
\hline $\begin{array}{l}\text { Vari- } \\
\text { able }\end{array}$ & Rationale & Definition & Literature \\
\hline tech & $\begin{array}{l}\text { The variable is used to capture } \\
\text { the impact of technology } \\
\text { intensity on divestment risk. } \\
\text { Subsidiaries in high-tech } \\
\text { industries might be more efficient } \\
\text { thus showing a relatively low } \\
\text { divestment risk. However, in the } \\
\text { Greek economy the location in } \\
\text { technology-intensive industries } \\
\text { might increase divestment risk } \\
\text { due to technology gap of the } \\
\text { economy (positive sign). }\end{array}$ & $\begin{array}{l}\text { tech is a dummy industry-specific } \\
\text { variable which takes the value } \\
\text { of } 1 \text { if the industry is technology } \\
\text { intensive and } 0 \text { otherwise }\end{array}$ & $\begin{array}{l}\text { Pennings and } \\
\text { Sleuwaegen } \\
2000, \\
\text { Mudambi } \\
\text { and Zahra } \\
2007\end{array}$ \\
\hline open & $\begin{array}{l}\text { The variable shows whether } \\
\text { foreign competition matters. The } \\
\text { operation in an open environment } \\
\text { might increase efficiency and } \\
\text { reduce divestment risk (negative } \\
\text { sign). }\end{array}$ & $\begin{array}{l}\text { Open is an industry-specific } \\
\text { variable and expresses the sum of } \\
\text { the import penetration (import/ } \\
\text { domestic consumption in \%) and } \\
\text { export orientation ratio (expo = } \\
\text { export sales/ total turnover in \%) } \\
\text { for each industry, that is Open } \\
\text { = import penetration + export } \\
\text { orientation }\end{array}$ & $\begin{array}{c}\text { Colantone } \\
\text { and } \\
\text { Sleuwaegen } \\
2010\end{array}$ \\
\hline
\end{tabular}

\section{Estimation Procedures}

We estimate the divestment risk by applying a complementary log-log model, which may be considered as the discrete time specification of the Cox proportional hazard model. The Cox model is one of the most important methods used for modeling survival analysis data by extending survival analysis to assess simultaneously the effects of several risk factors on survival time. In other words, it enables to examine how specific factors influence the rate of a particular event happening at a particular point of time. This rate is commonly referred as the hazard rate and is expressed by the hazard function. In turn, complementary log-log models are frequently used when the probability of an event is very small or very large. In particular, when the data given are not symmetric in the $[0,1]$ interval, the complementary $\log -\log$ might provide a satisfactory answer, thus out-performing other models such as logit and probit.

The generic model specification accounts for the four explanatory variables, tariff, labor, pdiff, and human, and a set of control variables enables us to consider potential identification issues: 
where $F($.$) is a nonlinear function on the set of explanatory and control variables of the form:$

$$
F(z)=1-e^{-e^{z}}
$$

The econometric analysis takes place within each integration stage and over the whole integration period (Table 3). For robustness reasons, the time dynamics of the explanatory variables on divestment risk are also considered by the incorporation of time dummies on the four explanatory variables as shown in Table 4 . The three economic integration stages are captured by three time dummies, each of which accounts for a unique stage of the economic integration period: Stage I, Stage II, and Stage III.

\section{Empirical Findings}

\section{A. Descriptive statistics}

Table 2 reports the descriptive statistics and correlations of the explanatory variables, indicating relatively low interdependencies between them $(<0.6$ in absolute terms); hence, there are no multicollinearity issues. In particular, the correlation coefficient of tariff and labor are negative $(-0.17)$ as tariff protection diminished at the beginning of the second stage while labor cost increased substantially until the middle of the second stage. In turn, there is a positive association (0.56) between pdiff and human that indicates a common action as driving location-bound factors (Table 2). Further, the correlation coefficient of pdiff and tariff $(-0.38)$ as well as that between human and tariff $(-0.48)$ are negative, producing contradictory divestment effects. Moreover, we calculated the Variance Inflation Factors (VIFs) for each model to account for potential multicollinearity issues. VIFs values were less than 4.10 and, therefore, below the cut-off value of 10.00 (Kutner et al. 2004), further indicating that multicollinearity does not affect our findings.

The descriptive analysis also provides evidence that the divested subsidiaries substantially differ from the non-divested units (Figure 5). Their main differences are in the variables pdiff, human, and tariff. Moreover, an important differentiation is shown in the variable expo, as non-divested subsidiaries are less export-oriented, apparently due to their strong localized nature. 


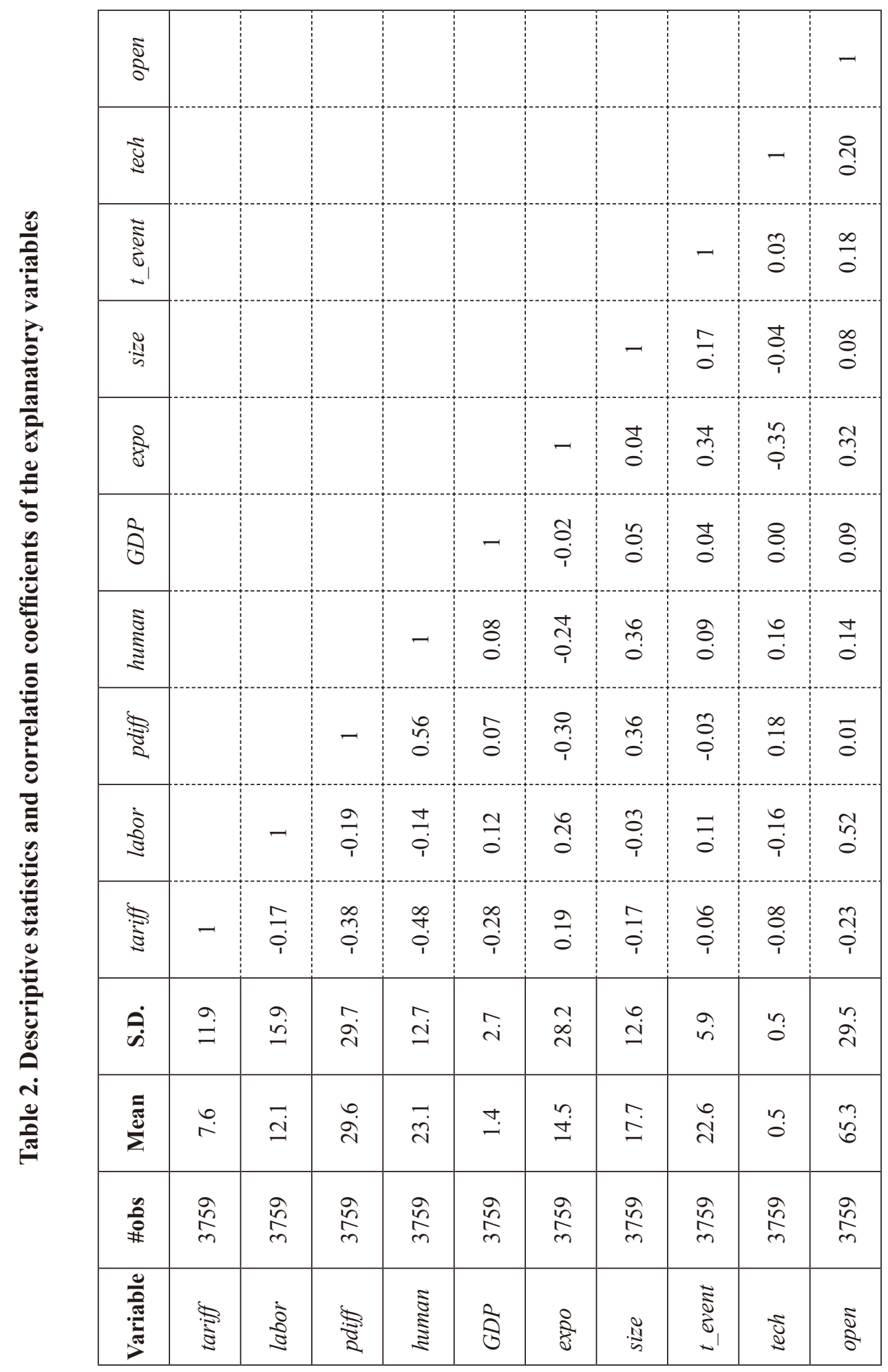




\section{Figure 5. Mean differences between non-divested and divested subsdiaries}

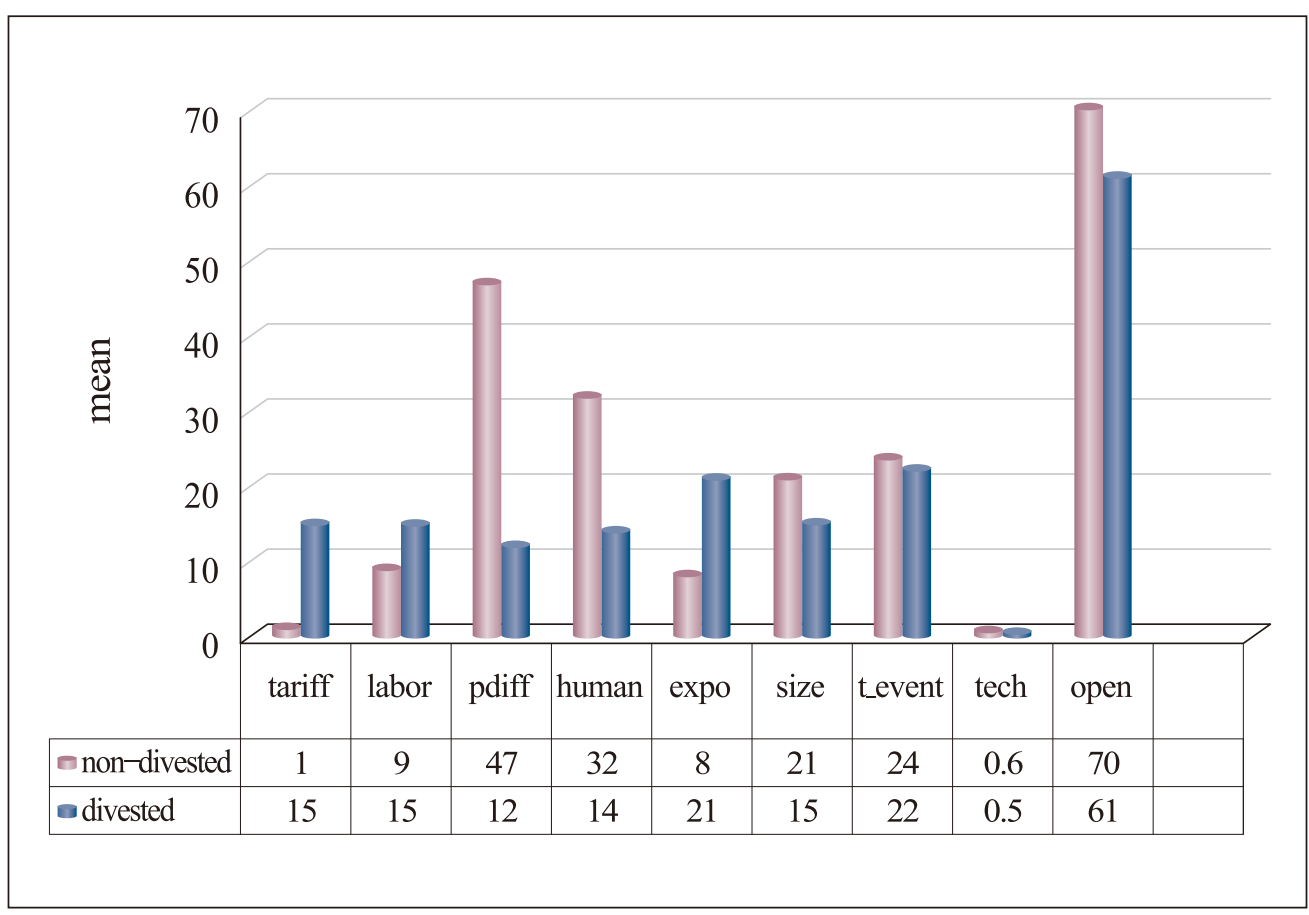

(Note) All $p$-values are at $1 \%$ level $(0.000)$

(Source) Processing of data of foreign Chambers of Industry and Commerce

\section{B. Econometric results}

The complementary log-log regression estimations are presented in Tables 3 and 4 . It should be mentioned that a positive sign of an estimated coefficient represents an increasing divestment risk in terms of closure of manufacturing unit and vice versa. Throughout the analysis, the industry classification is taken into account by using dummy variables. We partitioned 17 industries (NACE industrial classification, 4-digit level) into five categories along a continuum from traditional to non-traditional industries: Category 1:foods, beverages, and tobacco; Category 2: garments, textiles, leather, and paper; Category 3: chemicals, petroleum, and plastics; Category 4: non-metallic minerals, primary metals, and metal products; and Category 5: electrical products, machines, means of transportation, and other industries.

Table 3 captures the entire integration period as well as the three individual integration stages. The divestment risk effect of each of the four interpretive variables remains constant at each stage of integration. Thus, by moving from one stage to another, it becomes clear that the variables tariff, pdiff, and human, reduce divestment risk (negative sign), whereas labor augments the specific risk (positive sign). The coefficients of the variables indicate, 
respectively, the rate of increase $(+)$ or decrease $(-)$ of the divestment risk. For example, in the first integration stage, tariff reduces the probability of the specific risk by $21 \%$ while labor increases its probability by $10 \%$. In addition, pdiff and human reduce the likelihood of risk by $5 \%$ and $6 \%$, respectively. Analogous is the interpretation of the coefficients of the variables for the other integration stages.

The findings are statistically significant throughout all model specifications but with varying degrees of significance. More specifically, at the first integration stage, the variable tariff reduced divestment risk significantly atthe $1 \%$ level. However, at the beginning of the second stage, tariffs were totally abolished (Figure 2); hence, quantification of the tariff effect was not possible at the two late integration stages. During the whole integration period the variable reduced divestment risk to a specific degree (10\%). Labor increased divestment risk, revealing a different degree of significance over time (i.e., 10\% at Stage 1; 1\% at Stage 2; 5\% at Stage 3; and 1\% for the total investigation period). Further, pdiff exercised a negative impact on divestment risk with increasing influence over time (i.e., $10 \%$ at Stage $1 ; 1 \%$ at Stage $2 ; 5 \%$ at Stage 3; and $1 \%$ for the total investigation period). Very similar divestment risk effects as for product differentiation were also shown for human. Hence, increasing investment in these two location-bound factors increasingly limited divested risk as integration proceeded.

The variable $G D P$ had a decreasing impact on divestment risk at the second integration stage and during the whole period under investigation as well $(10 \%$ level). With regard to other control variables, export status, $t$ _event, and openness decreased divestment risk (statistically significant in almost all stages) and with varying importance. During the total period under investigation, their effects were significant at the 5\% level. In turn, operation in high-tech industries mostly augmented the specific risk, indicating that foreign production in these branches was sensitive to institutional change. Finally, subsidiary size provided rather contradictory results. At the first integration stage, its divestment risk impact was positive $(10 \%)$, with increasing significance in the total investigation period $(5 \%)$; however, at the third stage, its divestment risk effect was negative (10\%). 
Table 3. Divestment analysis for the whole integration period and for each integration stage

\begin{tabular}{|c|c|c|c|c|}
\hline Variables & $\begin{array}{c}\text { Integration } \\
\text { stage I } \\
\text { 1981 1991 } \\
\end{array}$ & $\begin{array}{c}\text { Integration } \\
\text { stage II } \\
\text { 1992 2001 } \\
\end{array}$ & $\begin{array}{c}\text { Integration } \\
\text { stage III } \\
2002 \sim 2015 \\
\end{array}$ & $\begin{array}{c}\text { Integration } \\
\text { total } \\
\text { 1981 2015 } \\
\end{array}$ \\
\hline tariff & $\begin{array}{c}-0.214^{* * *} \\
0.002\end{array}$ & $\&$ & $\&$ & $\begin{array}{c}-0.169^{*} \\
0.053\end{array}$ \\
\hline labor & $\begin{array}{c}0.102 * \\
0.084\end{array}$ & $\begin{array}{c}0.239 * * * \\
0.001\end{array}$ & $\begin{array}{c}0.888 * * \\
0.0321\end{array}$ & $\begin{array}{c}0.094 * * * \\
0.002\end{array}$ \\
\hline pdiff & $\begin{array}{c}-0.033^{*} \\
0.056\end{array}$ & $\begin{array}{c}-0.275^{* *} \\
0.034\end{array}$ & $\begin{array}{c}-0.536^{* * *} \\
0.000\end{array}$ & $\begin{array}{c}-0.155^{* * *} \\
0.000\end{array}$ \\
\hline human & $\begin{array}{c}-0.058 * \\
0.064\end{array}$ & $\begin{array}{c}-0.397^{* *} \\
0.028\end{array}$ & $\begin{array}{c}-0.814^{* * *} \\
0.000\end{array}$ & $\begin{array}{c}-0.128 * * * \\
0.000\end{array}$ \\
\hline$G D P$ & $\begin{array}{c}-0.018 \\
0.524 \\
\end{array}$ & $\begin{array}{c}-0.199 * \\
0.083\end{array}$ & $\begin{array}{l}0.316 \\
0.228\end{array}$ & $\begin{array}{c}-0.107^{*} \\
0.089\end{array}$ \\
\hline expo & $\begin{array}{c}-0.019 * \\
0.078\end{array}$ & $\begin{array}{c}-0.067 * * \\
0.043\end{array}$ & $\begin{array}{c}-0.622 * * \\
0.046\end{array}$ & $\begin{array}{c}-0.030 * * \\
0.023\end{array}$ \\
\hline size & $\begin{array}{c}0.026^{*} \\
0.089\end{array}$ & $\begin{array}{l}0.025 \\
0.466\end{array}$ & $\begin{array}{c}-0.271 * \\
0.092\end{array}$ & $\begin{array}{c}0.045^{* *} \\
0.037\end{array}$ \\
\hline t_event & $\begin{array}{c}-0.083^{*} \\
0.065\end{array}$ & $\begin{array}{c}-0.102 * \\
0.088\end{array}$ & $\begin{array}{c}-0.334 \\
0.355\end{array}$ & $\begin{array}{c}-0.213^{* *} \\
0.043\end{array}$ \\
\hline tech & $\begin{array}{l}0.339 \\
0.230\end{array}$ & $\begin{array}{c}1.598^{*} \\
0.052\end{array}$ & $\begin{array}{c}2.354 * * \\
0.0453\end{array}$ & $\begin{array}{c}0.554^{*} \\
0.087\end{array}$ \\
\hline open & $\begin{array}{c}-0.017^{*} \\
0.066\end{array}$ & $\begin{array}{c}-0.042 * \\
0.077\end{array}$ & $\begin{array}{c}-0.004 \\
0.112 \\
\end{array}$ & $\begin{array}{c}-0.018 * * \\
0.0211\end{array}$ \\
\hline$c$ & $\begin{array}{c}2.243^{*} \\
0.098 \\
\end{array}$ & $\begin{array}{c}5.925^{*} \\
0.097 \\
\end{array}$ & $\begin{array}{c}3.120^{*} \\
0.087\end{array}$ & $\begin{array}{c}4.712^{*} \\
0.098 \\
\end{array}$ \\
\hline \# of obs. & 1763 & 1153 & 837 & 5348 \\
\hline Prob (LR chi2) & 0.000 & 0.000 & 0.000 & 0.000 \\
\hline Log likelihood & -311 & -48 & -34 & -639 \\
\hline
\end{tabular}

(Notes) (i) *,**, and $* * *$ denote significance at $10 \%, 5 \%$ and $1 \%$, respectively

(ii) The numbers below the estimated parameters represent the corresponding $p$-values

(iii) \&: The tariff coefficient is omitted since at the beginning of the stage II protectionist measures are totally abolished

Next we explore alternative time-effects through a time-dummy on the four explanatory variables of the study (Table 4). New findings confirm the previous results. Tariff minimized divestment risk at the first integration stage (1\%). Labor cost generated a fluctuating effect 
on risk, whereas pdiff and human reduced divestment risk increasingly over the three stages. With regard to the control variables, we captured a declining divestment risk effect of GDP, expo, $t$ _event, and open, and an increasing risk effect in the case of size and high-tech industries.

Table 4. Divestment analysis for time dynamics -robustness test

\begin{tabular}{|c|c|c|}
\hline Variables & 1 & 2 \\
\hline tariff 1: stage I & $\begin{array}{c}-0.214 * * * \\
0.003\end{array}$ & $\begin{array}{c}-1.294 * * * \\
0.008\end{array}$ \\
\hline tariff 2: stage II & $\&$ & $\&$ \\
\hline tariff 3: stage III & $\underline{\&}$ & $\underline{\&}$ \\
\hline labor 1: stage I & $\begin{array}{c}0.092 * \\
0.078\end{array}$ & $\begin{array}{c}0.100^{*} \\
0.065\end{array}$ \\
\hline labor 2: stage II & $\begin{array}{c}0.445^{* * *} \\
0.003\end{array}$ & $\begin{array}{c}0.177 * * * \\
0.000\end{array}$ \\
\hline labor 3: stage III & $\begin{array}{c}0.902 * * \\
0.0255\end{array}$ & $\begin{array}{c}0.899 * * \\
0.031\end{array}$ \\
\hline pdiff 1: stage I & $-0.033^{*}$ & $\begin{array}{c}-0.275^{*} \\
0.064\end{array}$ \\
\hline pdiff 2: stage II & $-0.444 * *$ & $\begin{array}{c}-0.534 * * \\
0.045\end{array}$ \\
\hline pdiff 3: stage III & $\begin{array}{c}-0.675^{* * *} \\
0.000\end{array}$ & $\begin{array}{c}-1.209 * * * \\
0.000\end{array}$ \\
\hline human 1: stage I & $-0.058^{*}$ & $\begin{array}{c}-0.397^{*} \\
0.078\end{array}$ \\
\hline human 2: stage II & $\begin{array}{c}-0.245^{* *} \\
0.020\end{array}$ & $\begin{array}{c}-0.401 * * \\
0.015\end{array}$ \\
\hline human 3: stage III & $\begin{array}{c}-0.679 * * * \\
0.000\end{array}$ & $\begin{array}{c}-0.777 * * * \\
0.000\end{array}$ \\
\hline$G D P$ & & $\begin{array}{c}-0.015^{*} \\
0.097\end{array}$ \\
\hline expo & & $\begin{array}{c}-0.015^{* *} \\
0.042\end{array}$ \\
\hline size & & $\begin{array}{c}0.031^{*} \\
0.098\end{array}$ \\
\hline t_event & & $\begin{array}{c}-0.072^{* *} \\
0.022\end{array}$ \\
\hline tech & & $\begin{array}{c}0.346^{*} \\
0.087\end{array}$ \\
\hline open & & $\begin{array}{c}-0.026^{* *} \\
0.045\end{array}$ \\
\hline$c$ & $\begin{array}{c}1.355^{*} \\
0.087 \\
\end{array}$ & $\begin{array}{c}-0.359^{*} \\
0.076 \\
\end{array}$ \\
\hline \# of obs. & 5348 & 5348 \\
\hline Prob (LR chi2) & 0.000 & 0.000 \\
\hline Log likelihood & -436 & -435 \\
\hline
\end{tabular}


(Notes) (i) $* * *$, and $* * *$ denote significance at $10 \%, 5 \%$ and $1 \%$, respectively

(ii) The numbers below the estimated parameters represent the corresponding $p$-values

(iii) \&: The tariff coefficient is omitted since at the beginning of the stage II protectionist measures are totally abolished

\section{Discussion and Conclusion}

The study examined the path of foreign divestment risk in Greece while seriously taking into account the proposition of Krugman and Venable (1990) that the industrialization path of Southern European economies during European integration took a U-shaped form. The study's findings added new critical integration-political aspects in this interesting issue. First, the descriptive statistics largely confirmed the inverse U-shaped path of foreign divestment risk during the whole post-war era. In particular, they showed that MNE subsidiary risk remained very low during protectionism (high trade costs), subsequently rose when trade costs started to decrease (gradual replacement of protectionism through integration), and finally stabilized in later integration stages (low trade cost scenario). The path of foreign divestment risk we found was shaped by diverse contradictory forces that worked asymmetrically across the different integration stages of the economy. On the one hand, we found that product differentiation and human capital development guaranteed divestment risk reduction or stabilization at lower levels while on the other hand, the tariff reduction and labor cost increase strengthened the specific risk, thus producing controversial divestment scenarios in an EU context characterized by unity with diversity (Bliss and Braga de Macedo 1990 p.17). Especially Greece, due to its historical evolution and peripheral position, demonstrated some particular signs of consumer behavior that reinforced the development of highly differentiated brands (Georgopoulos and Preusse 2009) and the integration of distinctive market characteristics in business activity (Manolopoulos et al. 2007). Recent evidence (Georgopoulos and Preusse 2009) further supports our findings, indicating the importance of such localized assets for subsidiary performance. Moreover, we found that divestment risk stabilization at deeper integration stages was due to location-bound factors and not because of factor price differentials (as argued by Krugman and Venables 1990) that were unfavorable for MNE subsidiary survival in Greece during the years of regional integration (in Portugal as well, Simoes 2004).

The findings might support managers to be aware of an asymmetric divestment risk evolution during the integration procedure. Moreover, they might help policy makers to effectively manage economic adjustments and localization strategies to protect local brands at the international level and to promote targeted education policies. In addition, the study indicates that policy makers in emerging economies should support viable investment projects in attractive product segments of traditional industries when high-tech branches remain largely non-competitive in regional and international markets. In addition, economic policy can mitigate adverse integration effects by enhancing economic growth and promoting an effective labor market policy. The study's findings should be relevant for other peripheral European countries, such as Portugal and Spain, with comparable characteristics. Given 
that our empirical analysis is capable of replication, we hope that our findings will stimulate future research to address the research question on subsidiary divestment in other economies beyond Europe and with quite different historical data that might differentiate the macro divestment risk picture. Future research might also explore foreign subsidiary divestment (at parent-level as well) by considering diverse types of foreign units, such as majority affiliates, joint-ventures, etc. This research strategy would enable the utilization of a wider set of explanatory variables.

In summary, the study described the path of foreign divestment risk in the Greek economy, giving a new perspective on this issue through a 35-year analysis of the European integration process. We believe its main research contribution lies in the exploration of divestment risk evolution from one integration stage to the next, thereby covering an important gap in the relevant bibliography.

Received 5 November 2018, Revised 11 January 2019, Accepted 17 January 2019 


\section{References}

Anand, J., and Delios A. Absolute and relative resources as determinants of international acquisitions, Strategic Management Journal, 23 (2002): 119-134.

Belderbos, R. Antidumping and foreign divestments: Japanese electronics multinationals in the EU. Review of World Economics, 139 (2003): 131-160.

Benito, G.R.G. Divestment of foreign production operations, Applied Economics, 29(10) (1997): 1365-1378.

Benito,G.R.G., Grøgaard, B., and Narula R. Environmental influences on MNE subsidiary roles: economic integration and the Nordic countries, Journal of International Business Studies, 34 (5) (2003): 1-14.

Benito, G.R.G. Divestment and international business strategy, Journal of Economic Geography, 5 (2005): 235-251.

Bernard, A.B, and Jensen, J.B. Firm structure, multinationals and manufacturing plant deaths, The Review of Economics and Statistics, LXXXIX (2) (2007): 193-204.

Bliss, C., and Braga de Macedo, J. Introduction, in: Bliss C and Braga de Macedo J (eds.), Unity with diversity in the European economy: the Community's Southern frontier: Cambridge, Cambridge University Press, 1-17, 1990.

Caves R. E. International corporations: the industrial economics of foreign direct investment. Economica, 38 February (1971): 1-27.

Culem C. The location determinants of direct investments among industrialized countries. European Economic Review 32 (1988): 885-904.

Colantone I, Sleuwaegen L. International trade, exit and entry: A cross-country and industry analysis. Journal of International Business Studies, 41 (2010): 1240-1257.

Delios A., Beamish P.W. Survival and profitability: the roles of experience and intangible assets in foreign subsidiary performance. Academy of Management Journal 44 (5) (2001): 1028-1038.

Delios A., Xu D., Beamish P.W. Within-country product diversification and foreign subsidiary performance. Journal of International Business Studies39 (2008): 706-724. 
Fujita M., Krugman P. The new economic geography: Past, present and the future. Papers in Regional Science, 83 (2004): 139-164.

Georgopoulos, A., and Preusse, H.G. Cross-border acquisitions vs. Greenfield investment: A comparative performance analysis in Greece. International Business Review 18 (2009): 592605 .

Ghemawat P. Redefining global strategy, Boston MA: Harvard Business School Press (2007).

Krugman P. Scale economies, product differentiation, and the patterns of trade. American Economic Review 70 (5) (1980): 950-959.

Krugman P., Venables A.J. Integration and the competitiveness of peripheral industry. In Unity with diversity in the European economy: the Community's Southern frontier edited by Bliss, C. and De Macedo, JB. (1990): 56-77.

Krugman P., Venables A.J. Integration, specialization, and adjustment. European Economic Review, 40 (1996): 959-967.

Kutner M.H., Nachtsheim C.J., Neter J., \& Li W. Applied linear regression models, New York: McGraw-Hill/Irwin 2004.

Luo Y. Market-seeking MNEs in an emerging market: How parent-subsidiary links shape overseas success. Journal of International Business Studies, 34 (2003): 290-309.

Manolopoulos, D., Papanastassiou, M., and Pearce, R. Knowledge-related competitiveness and the roles of multinationals' R\&D in a peripheral European economy: survey analysis of Greece, Management International Review, 47 (5) (2007): 661-681.

Meyer, K., Mudambi, R., and Narula, R. Multinational enterprises and local contexts: the opportunities and challenges of multiple embeddedness, Journal of Management Studies, 48 (2) (2011): 235-252.

Mold, A. The impact of the Single Market Programme on the locational determinants of US manufacturing subsidiaries: an econometric analysis, Journal of Common Market Studies, 41 (1) (2003): 37-62.

Mudambi, R., and Zahra, S.A. The survival of international new ventures, Journal of International Business Studies,38 (2007): 333-352.

Murolo,A. The Greekeconomy: the role of the transnationals and theEEC, MezzogiornoD'Europa, 
Quarterly Review, 2 (1982): 197-220.

Narula, R., and Dunning, J. Industrial development, globalization and multinational enterprise: new realities for developing countries, Oxford Development Studies, 28 (2) (2000): 141-167.

Oughton, C. Growth, structural change and real convergence in the EC, in: European competitiveness, Hughes K.S. (eds): Cambridge University Press, 181-199, 1993.

Pearce, R., and Papanastassiou, M. European markets and the strategic roles of multinational enterprise subsidiaries in the UK, Journal of Common Market Studies,35 (2) (1997): 243-266.

Pennings, E, and Sleuwaegen, L. International relocation: firm and industry determinants, Economics Letters, 67 (2000): 179-186.

Perez-Batres, LA, and Eden, L. Is there a liability of localness? How emerging market firms respond to regulatory punctuations, Journal of International Management, 14 (2008): 232-251.

Richbell, S.W., and Watts, H.D. Plant closures in multiplant manufacturing firms: adding an internationalperspective, Management Decision, 38(2) (2000): 80-88.

Rozenzweig, P.M., and Nohria, N. Influences on human resource management practices in multinational corporations, Journal of International Business Studies, second quarter (1994): 229-251.

Simoes, V.C. (2004). Divestment by foreign-based companies: founding conditions, sourcing, and firm boundaries, $30^{\text {th }}$ EIBA Annual Conference: Enlarged European Union: Challenges to International Business and Management, Dec. 5-8, Ljubljana, Slovenia.

Young, S., Hood, N., and Peters, E. Multinational enterprises and regional economic development, Regional Studies, 28(7) (1994): 657-677. 